\title{
The impact of project manager's skills and age on project success
}

\author{
Maryam Elmezain (1) ', Wan Hamidon Wan Baduruzzaman', Muhamad Azry Khoiry \\ ${ }^{1}$ Universiti Kebangsaan Malaysia, Bangi, Malaysia.
}

How to cite: Elmezain, M., Baduruzzaman, W.H.W. and Khoiry, M.A. (2021), "The impact of project manager's skills and age on project success", Brazilian Journal of Operations \& Production Management, Vol. 18, No. 04, e2021950. https://doi.org/10.14488/BJOPM.2021.017

\begin{abstract}
Goal: This study seeks to examine project success in relation to project managers' factors. Pertaining to research questions, we highlighted: "do project manager's technical, conceptual, political and human skills are significantly related to project success?, and does project manager's age play a significant role in achieving project success?

Design / Methodology / Approach: This research employed a quantitative research method using survey questionnaires to collect data from 400 project managers working in five well-known construction companies in Cairo, Egypt. Descriptive statistics using Relative Importance Index (RII) were employed to rank the dimensions of project manager's skills: conceptual, technical, human and political skills; and project success dimensions: cost, schedule and quality. Multiple regression analysis was used to identify the impact of project managers' skills on project success while simple linear regression was used to examine the relationship between project manager's age and project success

Results: The results of RII revealed that project managers maintain a competitive level of technical, conceptual, political and human skills, and emphasize on specific aspects of cost, schedule, and quality dimensions of project success. The regression analysis revealed that $49.2 \%$ of the explained variation in project success can be accounted for technical, political, human and conceptual skills at coefficient of determination values of $0.611,0.506,0.431$ and 0.407 respectively while the project manager's age had no association with project success with a P value 0.694 at alpha level of 0.05 .

Limitations of the investigation: Generalizing research findings might be challenged because sample size was randomly selected due lack of identifying the exact size target population.

Practical implications: The managerial implication of this study lies in the need for construction companies not to consider project manager's age as a significant factor for project success, instead they need to ensure that project managers possess a competitive level of conceptual, technical, political and human skills.

Originality / Value: Pertaining to contribution to academia, this research argues that project success subject to a set of comprehensive set of project managerial skills namely conceptual, technical, political and human. Further, it is essential to distinguish between project manager's age and experience and not to consider project manager's age as a determinant of a project success.
\end{abstract}

Keyword: Project Manager's Skills; Project Manager's Age; Project Success; Construction Industry.

\section{INTRODUCTION}

Many organizations rely on projects to run operations and sustain their business success. Construction companies rely on projects to deliver a unique product or services to their

Financial support: None.

Conflict of interest: The authors have no conflict of interest to declare.

Corresponding author: mariamgalal95@outlook.com, wanhamidon@ukm.edu.my, azrykhoiry@ukm.edu.my

Received: 03 Apr 2020.

Approved: 17 Dec 2020.

Editor: Julio Vieira Neto 
customers. Construction companies rely on managing projects in their business activities and establishment of houses, apartments, condominiums, villas, schools, hospitals, bridges, airport, stores, malls, and roads. In handling a specific construction project, construction companies need to assign a project manager with relevant skills to ensure project success. Research acknowledges the significant role of project managers' skills in achieving project success (Hwang and Ng, 2013; Sunindijo, 2015).

Construction industry is one of the fundamental industries in Egypt with a remarkable impact on economic development and creation of employment opportunities. Egyptian government emphasizes the influential role of infrastructure and construction as the main drivers of financial stability and urban growth. Despite Covid-19 had a negative impact on construction industry, the demand for infrastructure and housing and infrastructure remain stable as the country's population continues to increase. According to a report by Oxford Business Group (2020), the Egyptian construction industry is expected to achieve longer-term growth driven by the growing trend of urbanisation and government support to double Egypt's urban area from $7 \%$ to $14 \%$ by 2052 . Based on a recent Fitch Ratings report, the Egyptian construction sector will continue its strong position throughout the next decade with a $9 \%$ annual growth rate between the years 2020-2024 (Refaat, 2020). Further, Refaat (2020) reported that the value of the current Egyptian construction industry is about 25 billion USD and estimated to reach more than $\$ 89$ billion by 2029 that represent about $30 \%$ of the value of the construction industry in the Middle East and North Africa region.

Researchers and professional believe that the project manager is a very essential element to the success of the construction project and have an impact at every stage of the construction project as argued by Ali and Chileshe (2009). Within today's competitive market, the recognition and growth of project managers ' skills is becoming increasingly important (Omidvar et al, 2012). El-sokhn and Othman (2014) argued that the construction sector is regarded for its persistent problems of fragmentation, low productivity, time and value overruns; bad safety, inferior working conditions, and inadequate excellent which finally leads to project failure and terrible development images. A project manager needs knowledge and expertise to handle the construction project effectively and efficiently (Hwang and Ng, 2013). A project manager with integrity is important to the necessity and progress of the project. This study was centered on the assumption that project success can be predicted by project managers' skills guided by Blaskovics (2016) argumentation that project managers play a key part in achieving project success.

Subsequent sections present a brief review of the literature considering project success, project manager's skills and age along with hypotheses development.

\section{LITERATURE REVIEW}

This section presents a review of the literature on project success, relationship between project managers' skills and project managers' age and project success.

\section{Project Success}

The success of construction projects is an important issue for most governments, users and communities. Muller (2007) indicated that the projects vary in size, uniqueness and difficulty. Although many papers on project success have been published, there is no consensus on it (Jiang et al, 2016). In modern construction projects, customers and contractors are having great difficulty completing the project due to the increasing complexity in designing and involving stakeholders (Doloi, 2009). Standish Group (2015) reported that only 5\% of projects are considered successful and that a high rate of project failure can negatively impact business profitability. Gunduz and Yahya (2018) stressed the need to identify and analyze the factors associated with the success and failure of building projects in recent decades. Project managers can increase the chances of successful completion of projects and fulfill all requirements by applying management tools during project planning and implementation 
phases (Gunduz and Yahya, 2018). Researchers presented various conceptualization of project success as shown in Table 1. Former research focused on achieving the iron triangle goals of project success: time, cost and quality (Atkinson, 1999; Wateridge, 1998).

Table 1. Selected conceptualizations of Project Success Dimensions

\begin{tabular}{ccccccc}
\hline Author/s & Cost & Schedule & Quality & Performance & $\begin{array}{c}\text { Operating } \\
\text { environment }\end{array}$ & Safety \\
\hline $\begin{array}{c}\text { Hughes, Tippett, and } \\
\text { Thomas (2004). }\end{array}$ & $\sqrt{ }$ & $\sqrt{ }$ & $\sqrt{ }$ & $\sqrt{ }$ & $\sqrt{ }$ & $\sqrt{ }$ \\
\hline Chan and Chan (2004) & $\sqrt{ }$ & $\sqrt{ }$ & $\sqrt{ }$ & $\sqrt{ }$ & & \\
\hline Chen (2008) & $\sqrt{ }$ & $\sqrt{ }$ & $\sqrt{ }$ & $\sqrt{ }$ & & \\
\hline Morteza. et al. (2008) & $\sqrt{ }$ & $\sqrt{ }$ & $\sqrt{ }$ & & $\sqrt{ }$ & \\
\hline Sigurðarson (2009) & $\sqrt{ }$ & $\sqrt{ }$ & $\sqrt{ }$ & $\sqrt{ }$ & $\sqrt{ }$ \\
\hline Kerzner (2009) & $\sqrt{ }$ & $\sqrt{ }$ & $\sqrt{ }$ & $\sqrt{ }$ & $\sqrt{ }$ \\
\hline Wai et al. (2012) & $\sqrt{ }$ & $\sqrt{ }$ & $\sqrt{ }$ & $\sqrt{ }$ & $\sqrt{ }$ \\
\hline Alzahrani and Emsley & $\sqrt{2013)}$ & $\sqrt{ }$ & $\sqrt{ }$ & & $\sqrt{ }$ \\
\hline Khan et al. (2013) & $\sqrt{ }$ & $\sqrt{ }$ & $\sqrt{ }$ & $\sqrt{ }$ & \\
\hline Zare et al. (2016). & $\sqrt{ }$ & $\sqrt{ }$ & $\sqrt{ }$ & & $\sqrt{ }$ \\
\hline Al-Shaaby and Ahmed & $\sqrt{2018)}$ & $\sqrt{ }$ & $\sqrt{ }$ & $\sqrt{ }$ & $\sqrt{ }$ \\
\hline Silva et al. (2019) & $\sqrt{ }$ & $\sqrt{ }$ & $\sqrt{ }$ & $\sqrt{ }$ &
\end{tabular}

However, recent literature advocated the need to add new measures to project success such safety and operating environment. It is evident that most of the researchers still focus on the fundamental three dimensions of project success: cost, quality and schedule. However, scholars also added new dimensions such as performance, operating environment and safety. Despite the importance of all dimensions of project success, this research builds on the first three dimensions only. Guided by the nature of construction projects in Egypt and first author's knowledge and close relationship with many construction engineers, we believe that these three dimensions are relevant and highly appreciated in the Egyptian context.

\section{Project Manager's Skills}

The project manager with integrity is important to the necessity of the project, its progress, and its successful attainment. Researchers and professionals believe that the project manager is a very essential element to the success of the construction project and have an impact at every stage of the construction project (Ali and Chileshe, 2009). In today's competitive market, the recognition and growth of project manager's skills becoming increasingly important (omidvaret et al, 2012).

A competent project manager is vital to project success, and various studies have highlighted critical expertise (Hwang and $\mathrm{Ng}$, 2013). The Authors confirmed the construction industry's growing awareness of the relationship between achieving project success and construction project management competencies. A majority of competency for enlarging and achieving project management is the management skill in leadership (98.2\%) while minority expertise is technique skill in planning and scheduling (97.3\%) as reported by (Khamaksorn, 2016).

Sunindijo (2015) indicated that interpersonal influence has positive relationship with project time performance. Katz (1974) is one of the pioneers who investigated effective managerial skills. He examined the skills which executives exhibited to carry out their jobs 
effectively. He suggested three basic developable skills namely technical, human, and conceptual skills. Katz (1974) defined technical skill as the "specialized knowledge, analytical ability within that specialty, and facility in the use of the tools and techniques of the specific discipline"; human skill as "the ability to work effectively as a group member and to build cooperative effort within the team"; and conceptual skill as the "ability to see the enterprise as a whole including recognizing how the various functions depend on one another and how changes in one part can affect all the others", Various researchers stressed the value of political skill (Ahearn et al., 2004; Ferris et al., 2005b; Sunindijo and Zou, 2012). Political skill is defined as "the ability to understand others at work and to use that knowledge to influence others to act in ways that enhance one's personal or organizational objectives" (Ferris et al., $2005 b$, p. 7). This research argues that political skill is important in achieving project success in construction industry. Table 2 illustrates the main conceptualization of project managers' skills.

Table 2. Conceptualizations of Project Managers' Skills

\begin{tabular}{|c|c|c|c|c|}
\hline Authors & $\begin{array}{c}\text { Conceptual } \\
\text { skills }\end{array}$ & $\begin{array}{c}\text { Human } \\
\text { skills }\end{array}$ & $\begin{array}{c}\text { Political } \\
\text { skills }\end{array}$ & $\begin{array}{c}\text { Technical } \\
\text { skills }\end{array}$ \\
\hline Katz (1974) & $\sqrt{ }$ & $\bar{V}$ & - & $\sqrt{ }$ \\
\hline Goodwin (1993) & $\sqrt{ }$ & $\sqrt{ }$ & $\sqrt{ }$ & $\sqrt{ }$ \\
\hline Gushgari et al. (1997) & $\sqrt{ }$ & $\sqrt{ }$ & - & $\sqrt{ }$ \\
\hline El-Sabaa (2001) & $\sqrt{ }$ & $\sqrt{ }$ & $\sqrt{ }$ & $\sqrt{ }$ \\
\hline Lientz and Rea (2002) & $\sqrt{ }$ & $\sqrt{ }$ & & $\sqrt{ }$ \\
\hline Dainty et al. (2003) & $\sqrt{ }$ & $\sqrt{ }$ & $\sqrt{ }$ & - \\
\hline Lei and Skitmore (2004) & $\sqrt{ }$ & $\sqrt{ }$ & $\sqrt{ }$ & $\sqrt{ }$ \\
\hline Peterson and Peterson (2004) & $\sqrt{ }$ & $\sqrt{ }$ & - & $\sqrt{ }$ \\
\hline Dainty et al. (2005) & $\sqrt{ }$ & $\sqrt{ }$ & $\sqrt{ }$ & - \\
\hline Gillard and Price (2005) & $\sqrt{ }$ & $\sqrt{ }$ & $\sqrt{ }$ & - \\
\hline Ferris, Kolodinsky et al (2005b) & - & - & $\sqrt{ }$ & - \\
\hline Brill et al. (2006) & $\sqrt{ }$ & $\sqrt{ }$ & $\sqrt{ }$ & $\sqrt{ }$ \\
\hline Chen et al. (2008) & $\sqrt{ }$ & $\sqrt{ }$ & $\sqrt{ }$ & $\sqrt{ }$ \\
\hline Farooqui et al (2008) & $\sqrt{ }$ & $\sqrt{ }$ & $\sqrt{ }$ & $\sqrt{ }$ \\
\hline Kerzner (2009) & $\sqrt{ }$ & $\sqrt{ }$ & - & $\sqrt{ }$ \\
\hline PMI (2013) & $\sqrt{ }$ & $\sqrt{ }$ & $\sqrt{ }$ & $\sqrt{ }$ \\
\hline Sunindijo (2015). & $\sqrt{ }$ & $\sqrt{ }$ & $\sqrt{ }$ & $\sqrt{ }$ \\
\hline Adams (2016) & - & $\sqrt{ }$ & - & $\sqrt{ }$ \\
\hline Obradović et al (2018). & $\sqrt{ }$ & $\sqrt{ }$ & $\sqrt{ }$ & $\sqrt{ }$ \\
\hline
\end{tabular}

Extant literature advocates the importance of the project manager and his strong role in leading the project to success. Further, Zulkiffli and Lattifi (2019) indicated that project managers played a vital role in sustainable building projects by integrating sustainability into their practices. In all phases of sustainable construction projects, the role of project manager is important, but especially in the pre-construction phase when the greatest challenges that require their involvement are present. This requires project managers to have effective leadership skills to think through a project and stay focused on the ultimate goal. To manage the project professionally and successfully, a project manager needs to possess the required knowledge and skills (Hwang and Ng, 2013). Sunindijo (2015) advocated that previous research has determined four skills of effective project managers with significant impact on project success namely, conceptual, human, political, and technical skills. Research employs various 
categorizations of managerial skills in relation to project success. This research argues that technical, conceptual, political, and human skills provides a comprehensive explanation and cover all dimensions of project success in construction industry.

\section{Hypotheses Development}

\section{Manager's Technical Skills and Project Success}

In order to successfully manage construction projects, project managers need to possess technical skills. Construction project managers have to combine technical knowledge and expertise with skills that can assure effective coordination and communication of many different stakeholders (Dainty et al., 2005). Khamaksorn (2016) revealed that scheduling and planning management is a significant knowledge while delegation, leadership, decision making and problem solving are the essential skills for the construction process. Moreover, project manager is a key person who is responsible for the construction project success. It is important that construction project manager must have technical and managerial skills (Khamaksorn, 2016). Decision-making and problem-solving skills involve the ability to define and solve problems. Decision making is a process of obtaining a team commitment to, and collective support for, sustainability (Zulch, 2014). For example, in the planning and design stage, there is a need for the project manager to decide the best possible selection of technologies, systems, and subcontractors required for green projects (Hwang and Ng, 2013). Based on the above discussions, may argue that project manager's technical skills have a significant impact on project success. Therefore, the first hypothesis can be stated as:

H1: Project manager's technical skills have significant positive impact on project success

\section{Project Manger's Human Skills and Project Success}

Motivating and leading and communicating with workers and employees are a vital task performed by project managers in the construction industry. For instance, communication is especially important for project managers in green projects in order to deliver the sustainable practices that are expected from the project team (Delnavaz, 2012). At the initial stage, a project manager needs to successfully communicate with stakeholders about achieving its sustainability goals (Serhan, 2016). The skill of motivation is an ability to enable a person to achieve their goals. Yet, motivation is a skill that a project manager can apply to ensure that the project team achieves the project's goals in time and on budget (Schmid and Adams, 2008). In the early phase of a sustainable construction project, a project manager needs to motivate the project team in order to achieve sustainability goals. However, the lack of such motivation often leads to conflict, strikes, low productivity, stress, and the failure of the project (Zulch, 2014). Project teams have lower levels of motivation when they are not fully aware of the green project process (Robichaud and Anantatmula, 2011). Besides, motivation is the key to ensure that the stakeholders, such as the project owner and the developers, constantly engage with green building practices (Olanipekun et al., 2017). Team building skills are one of fundamental human skills that project managers should possess. Teams are defined as groups of people who have skills that are committed to a common purpose and who hold themselves mutually responsible for its achievement (Foley and Macmillan, 2005). The results of a survey from Singapore revealed that project managers who are equipped with good team building skills can improve project team cohesiveness as well as enhancing the overall project team performance (Hwang and Ng, 2013). Hence, project manager's human skills have a significant impact on project success. The second research hypothesis is stated as follows:

H2: Project manager's human skills have significant positive impact on project success

\section{Project Manager's Political Skills and Project Success}

To achieve the perfect teamwork project manager has to understand his team mind and how to deal with them, also to understand everyone he deals with to get to a point which leads 
the project to success. Former research conducted by Mainiero (1994) and Spencer and Spencer (1993) suggested that well-developed political skill is an important contributor that distinguishes superior performers. Sunindijo and Zou (2012) also found that political skill can be used to develop safety climate in construction projects. Furthermore, research has confirmed that political skill is empirically distinct from human skill components like social intelligence, emotional intelligence, trait anxiety, ego-resiliency, social self-efficacy, and general mental ability (Ferris et al., 2005b). Conflict management has also been identified as one of the important soft skills that influence the achievement of project success by the project managers (Giotis, 2010).

In addition, the project manager should pay close attention to the coordination between design consultants and the construction team as well as to the technology innovations so that the likelihood of success in green building projects can be enhanced (Li et al., 2013). Delegation skill involves working with subordinates to establish direction, authority, and responsibility which enable a project manager to manage the team and deliver results will be limited (Khamaksorn, 2016). Project manager should negotiate among stakeholders and the project team about various aspects of the pre-construction phase such as the scope of the project, deadlines, resources, the team structure that is required to deliver the project, targeted achievements and other things that occur during the project (Foley and Macmillan, 2005). Accordingly, project manager's political skills are entitled to induce a significant impact on project success. The third hypothesis is withdrawn as:

H3: Project manager's political skills have significant positive impact on project success

\section{Project Manager's Conceptual Skills and Project Success}

Conceptual skills are related to overall planning of the project. Planning and goal setting skills involve an ability to plan a process and to achieve the desired goals. During the planning and scheduling process, a project manager should consider the impact of green criteria on the overall schedule for the construction works (Glavinich, 2008). The plan of work should be explained to all parties (stakeholders and the project team) such as in the pre-start meeting where all parties need to work together to establish project feasibility so that the project manager can implement a smooth construction schedule (Robichaud and Anantatmula, 2011). Besides that, setting feasible and sustainable priorities during the project will help to establish a framework for all future decision making (Farooqui, 2008). Katz (1974) added that conceptual skill extends to visualising the relationships of the business to the industry, the community, and the political, social, and economic conditions as a whole. A project manager is responsible for integrating and coordinating all activities in the project. Therefore, we may say that project manager's conceptual skills have a significant impact on project success. The fourth hypothesis is addressed as:

H4: Project manager's conceptual skills have a significant positive impact on project success

\section{Project Manager Age and Project Success}

Organizations rely on young and old employees in conducting their businesses and achieving organizational objectives. Hoxha and Mcmahan (2019) argued that age is one of the most prevalent form of discrimination in workplaces and reported that project managers' age did not significantly predict project success. Advanced wellness and healthcare as well as elimination of obligatory retirement creates a new challenge for a more age-diverse workforce (Lain and Loretto, 2016). Schreiber (2015) noted that younger leaders were less accepted, which, in turn, impacted team effectiveness. Younger engineers have a higher work performance than older engineers (Santoso and Kulathunga, 2016). Compared to younger project managers, older project managers allocated greater significance on project control and extra-organizational objectives (Chipulu et al., 2014). In their study, Ojiako et al. (2015) claimed agreements between stakeholders and project managers are also influenced by age. During project implementation and handover stages, older project managers had more 
chance of changing their initial judgment (Ojiako et al., 2015). Larsson et al. (2015) argued that project success is not influenced by project managers' age. Further, Blaskovics (2016) noted that project managers are instrumental for project success. Based on these argumentations, project manager's age is significantly associated with project success in construction industry. The fifth research hypothesis is stated as follows:

H2: Project manager's age has a significant impact on project success

Figure 1 visualizes the proposed conceptual framework. It is clear that the independent variables are the project manager's skills namely political, human, technical and technical skills, and project manager's age. On the other hand, this research uses project success as the dependent variable.

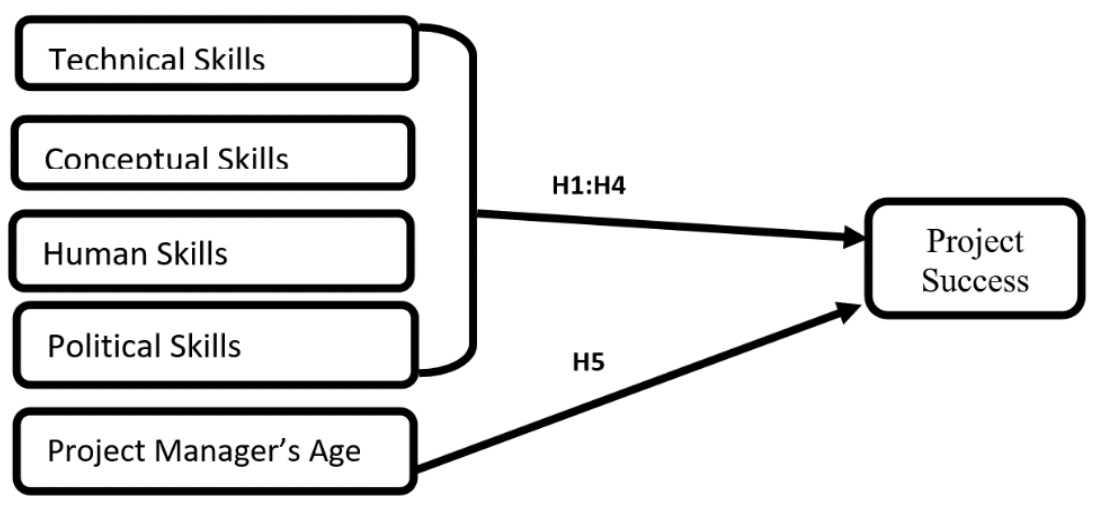

Figure 1: Conceptual Framework

\section{METHODOLOGY}

This research uses a quantitative method by which data collection employed a survey questionnaire. The participants in this study were Egyptian project managers working in Cairo or Giza in construction industry. The sample size employed for this research was 400 project managers in Egyptian construction industry of the major players in Egyptian construction industry are Ahly Development, Alex Group, Amer Group, Palm Hills Development and Redcon Construction. SPSS was used for data analysis by which multiple regression analysis was used to examine the hypothetical relationship between political, human, conceptual and technical skills in relation to project success. Generally, multiple regression explains the relationship between multiple independent variables and one dependent variable (Bryman, 2012). On the other hand, simple linear regression was used to examine the relationship between project manager age and project success.

This research uses two general independent variables: project manager's skills and project age. Project manager's skills were conceptualized based on Sunindijo (2015) categorization of project management skills divided into technical, political, conceptual and human skills. On the other hand, project manager's age is a categorical variable and measured by the researcher based on identifying age groups ranging from 25 to 65 years. The dependent variable, project success was measured using Khan et al. (2013) scale using a five-point Likert scale format ranging from 'strongly disagree' to 'strongly agree'. At a preliminary stage of data collection, a pilot study was conducted to assess the reliability of survey questionnaire. A total of 50 questionnaires were distributed to construction engineers and allowed one week to fill it. Only 30 questionnaires were valid for data analysis. The reported Cronobach alpha scales were above 0.7 , hence we decided to proceed to actual data collection. Overall, a total of 650 survey questionnaires were distributed to project managers with only 430 returned and 400 completed and valid for data analysis. SPSS was used for data analysis because of its popularity within both academic and professional contexts and its ability to analyze data for larger sample sizes. 


\section{ANALYSIS AND DISCUSSION OF RESULTS}

Table 3 reports the profile of the respondents. Majority of project managers were males (77.5\%) with Bachelor's degrees (64.5\%). Around 35\% of project managers aged 50 years and above followed by $30 \%$ aged $40-49$ years. Work experience as a project manager revealed that $31 \%$ of respondents possess $8-12$ years followed by $27 \%$ with $13-20$ years of experience. Further, $38 \%$ of respondents are involved in residential projects followed by $21 \%$ school projects.

Prior to embarking on data collection, we assessed the reliability of survey questionnaire. This research builds on (Hair et al., 2006) statements that coefficient alpha values of 0.70 and above are entitled to represent acceptable reliability, those above 0.80 represent good reliability, and those above 0.90 represent excellent reliability. The results of Cronbach alpha test revealed project managers' skills and project success showed coefficient alpha values of 0.876 and 0.813 respectively. Therefore, the employed research instrument maintains a good reliability.

Table 3. Project Managers' Profile

\begin{tabular}{|c|c|c|}
\hline Item & Frequency & Percent (\%) \\
\hline \multicolumn{3}{|l|}{ Gender } \\
\hline Male & 310 & 77.50 \\
\hline Female & 90 & 22.50 \\
\hline \multicolumn{3}{|l|}{ Age } \\
\hline $25-29$ & 53 & 13.25 \\
\hline $30-39$ & 88 & 22.00 \\
\hline $40-49$ & 119 & 29.75 \\
\hline 50 and Above & 140 & 35.00 \\
\hline \multicolumn{3}{|l|}{ Work Experience } \\
\hline $1-3$ years & 42 & 10.50 \\
\hline 4-7 years & 74 & 18.50 \\
\hline $8-12$ years & 123 & 30.75 \\
\hline 13-20 years & 107 & 26.75 \\
\hline Above 20 years & 54 & 13.50 \\
\hline \multicolumn{3}{|l|}{ Project type } \\
\hline Offices building & 73 & 18.25 \\
\hline Residential & 152 & 38.00 \\
\hline Hospital & 68 & 17.00 \\
\hline School & 87 & 21.75 \\
\hline Others & 20 & 5.00 \\
\hline \multicolumn{3}{|l|}{ Education Level } \\
\hline Bachelor & 259 & 64.75 \\
\hline Master & 108 & 27.00 \\
\hline $\mathrm{PhD}$ & 33 & 8.25 \\
\hline
\end{tabular}

In assessing the Relative Importance Index (RII), this study adopted used SPSS based on the equation used by Muhwezi et al. (2014), where the scores assigned to each type of skill reflected by the respondents.

$\mathrm{RII}=\frac{\sum \mathrm{W}}{\mathrm{A} * \mathrm{~N}}(0 \leq \mathrm{RII} \leq 1)$ 
Where:

W: the weight given to each factor ranging from 1(strongly disagree) to 5 (strongly agree);

A: the highest weight (i.e. 5 in this case) and

$\mathbf{N}$ : the total number of respondents.

Table 4. Relative Importance Index for Project Managers' Skills

\begin{tabular}{|c|c|c|c|}
\hline Variable & Items & RII & Rank \\
\hline \multirow{3}{*}{$\begin{array}{l}\text { Conceptual } \\
\text { Skills }\end{array}$} & Determine and coordinate project elements and resources & 0.892 & 1 \\
\hline & Identify exactly what needs to be involved in a project & 0.826 & 2 \\
\hline & $\begin{array}{l}\text { Maintain a Grandview of a project and its relationships to company, } \\
\text { environment, community and industry. }\end{array}$ & 0.794 & 3 \\
\hline \multirow{3}{*}{$\begin{array}{l}\text { Human } \\
\text { Skills }\end{array}$} & Motivates and inspires subordinates to effectively perform their tasks & 0.865 & 1 \\
\hline & Effectively communicate with a variety of people & 0.843 & 2 \\
\hline & $\begin{array}{l}\text { Recognize the feelings of his/her own and subordinates' feelings to } \\
\text { maintain self-motivation and managing others' emotions }\end{array}$ & 0.811 & 3 \\
\hline \multirow{4}{*}{$\begin{array}{l}\text { Political } \\
\text { Skills }\end{array}$} & $\begin{array}{l}\text { Advocate high levels of integrity, sincerity and authenticity ,, to } \\
\text { inspires confidence and trust in others }\end{array}$ & 0.872 & 1 \\
\hline & $\begin{array}{l}\text { Create and employ various social networks to achieve organizational } \\
\text { and personal goals }\end{array}$ & 0.855 & 2 \\
\hline & $\begin{array}{l}\text { Permit followers to adapt their behavior to diverse situations to } \\
\text { stimulate the desired responses }\end{array}$ & 0.842 & 3 \\
\hline & $\begin{array}{l}\text { Recognize interpersonal interactions and social situations that occur } \\
\text { in social settings }\end{array}$ & 0.783 & 4 \\
\hline \multirow{6}{*}{$\begin{array}{l}\text { Technical } \\
\text { Skills }\end{array}$} & $\begin{array}{l}\text { Identify resources (human and financial) required to implement } \\
\text { project activities such as setting and controlling project budget }\end{array}$ & 0.914 & 1 \\
\hline & $\begin{array}{l}\text { Understand construction contracts' standard procedures and take } \\
\text { responsibility of document management system }\end{array}$ & 0.861 & 2 \\
\hline & $\begin{array}{l}\text { Determine quality standards, methods to meet the standards, } \\
\text { monitor compliance and eliminate inadequate performance }\end{array}$ & 0.742 & 3 \\
\hline & $\begin{array}{l}\text { Decide on which tasks need to be performs, which tasks are due and } \\
\text { which activities drive other activities }\end{array}$ & 0.738 & 4 \\
\hline & $\begin{array}{c}\text { Effectively manage processes related to achieving goals, services and } \\
\text { results required from external parties }\end{array}$ & 0.709 & 5 \\
\hline & Conduct risk management such a identify, analyze and mitigate risks & 0.683 & 6 \\
\hline
\end{tabular}

Table 4 showed the Relative Importance Index findings related to project managers' conceptual, human, political and technical skills. The results of Relative Importance Index showed that Egyptian construction project managers possess effective conceptual skills as they emphasized identification and coordination of project resources and elements (0.892), aware of what exactly should be involved in a project $(0.826)$ and finally maintain a macro view of the whole project and its association with company, industry and community (0.794). For human skills, project managers had the abilities to motivates and inspires subordinates to effectively perform their tasks (0.865), communicate effectively with a variety of people (0.843), recognize their feelings and their subordinates' feelings to maintain self-motivation and managing others' emotions (0.811). For political skills, project managers revealed that they advocate high levels of integrity, sincerity and authenticity, to inspires confidence and trust in others (0.872), create and employ various social networks to achieve organizational and personal goals $(0.855)$, permit followers to adapt their behavior to diverse situations to stimulate the desired responses (0.842) and recognize interpersonal interactions and social situations that occur in social settings $(0.783)$. For the technical skills, project managers had the abilities to identify resources (human and financial) required to implement project 
activities such as setting and controlling project budget (0.914), understand construction contracts' standard procedures and take responsibility of document management system (0.861), determine quality standards, methods to meet the standards, monitor compliance and eliminate inadequate performance (0.742), decide on which tasks need to be performs, which tasks are due and which activities drive other activities (0.738), effectively manage processes related to achieving goals, services and results required from external parties (0.709) and conduct risk management such a identify, analyze and mitigate risks (0.683). It was evident that Egyptian project managers had sufficient level of technical, political, human and conceptual skills.

Table 5. Relative Importance Index for Project Success

\begin{tabular}{|c|c|c|c|}
\hline Variables & Items & RII & Rank \\
\hline \multirow{5}{*}{ Cost } & Net profit targets were met & 0.841 & 1 \\
\hline & $\begin{array}{l}\text { Overall project cost performance was met based on baseline goals, } \\
\text { targets, or expectations. }\end{array}$ & 0.793 & 2 \\
\hline & Budget contingencies were well managed. & 0.751 & 3 \\
\hline & Rework costs were well managed. & 0.682 & 4 \\
\hline & Market competition was well understood. & 0.516 & 5 \\
\hline \multirow{5}{*}{ Schedule } & Labor availability was well managed. & 0.885 & 1 \\
\hline & $\begin{array}{l}\text { Overall project schedule performance was met based on baseline goals, } \\
\text { targets, or expectations. }\end{array}$ & 0.793 & 2 \\
\hline & Equipment availability was well managed. & 0.778 & 3 \\
\hline & Schedule float management was optimized & 0.704 & 4 \\
\hline & Material availability was well managed. & 0.624 & 5 \\
\hline \multirow{4}{*}{ Quality } & Customer satisfaction was evidenced by direct feedback. & 0.872 & 1 \\
\hline & $\begin{array}{l}\text { Overall project quality objectives were met based on baseline goals, } \\
\text { targets, or expectations. }\end{array}$ & 0.809 & 2 \\
\hline & $\begin{array}{l}\text { Customer satisfaction was evidenced by the opportunity for follow-on } \\
\text { work. }\end{array}$ & 0.782 & 3 \\
\hline & $\begin{array}{c}\text { The customer's true goals and expectations were properly reflected in } \\
\text { contract performance incentives. }\end{array}$ & 0.661 & 4 \\
\hline
\end{tabular}

The results of Relative Importance Index for project success are summarized in Table 5. Findings showed that Egyptian construction project managers emphasize on specific aspects of cost, schedule, and quality dimensions. For cost dimensions, respondents reported that net profit targets were met $(0.841)$, overall project cost performance was met based on baseline goals, targets, or expectations (0.793), budget contingencies were well managed (0.751), rework costs were well managed (0.682), and market competition was well understood (0.516). For schedule dimensions, respondents revealed that labor availability was well managed (0.885), overall project schedule performance was met based on baseline goals, targets, or expectations (0.793), equipment availability was well managed $(0.778)$, schedule float management was optimized (0.704), and material availability was well managed (0.624). For quality dimensions, respondents indicated that customer satisfaction was evidenced by direct feedback (0.872), overall project quality objectives were met based on baseline goals, targets, or expectations (0.809), customer satisfaction was evidenced by the opportunity for follow-on work (0.782), and the customer's true goals and expectations were properly reflected in contract performance incentives $(0.661)$.

Table 6 presents a summary of multiple regression analysis of human, technical, conceptual and political skills on the dependent variable project success. It is evident that the 
regression model achieve a high degree of fit, as reflected by " $R$ " and "R2" value $0.748,0.492$ respectively, which revealed that $49.2 \%$ of the explained variation in project success can be accounted for technical, political, human and conceptual skills.

Table 6. Summary of multiple regression results

\begin{tabular}{cccc}
\hline & B & T-value & Sig* \\
\hline Technical Skills & 0.611 & 5.407 & 0.000 \\
\hline Human Skills & 0.506 & 4.346 & 0.012 \\
\hline Political Skills & 0.431 & 3.561 & 0.000 \\
\hline Conceptual Skills & 0.407 & 3.438 & 0.018 \\
\hline
\end{tabular}

R 0.748; R² 0.492; F 24.784; Sig* 0.000; N 400

\section{Dependent Variable: Project Success}

From the above research findings, it can be stated that for a one unit increase in technical, political, human and conceptual skills is predicted to have a $0.611,0.506,0.431$ and 0.407 increases in project success. Further, the analysis of variance of the fitted regression equation is significant with $\mathrm{F}$ value of 24.784 . This is an indication that the model is a good one. Since the p-value is less than 0.05 , it shows a statistically significant relationship between the variables at 0.95 confidence level. Accordingly, in technical, political, human and conceptual skills have a significant positive effect on project success.

Table 7. Simple Linear Regression: Manager's age and Project Success

\begin{tabular}{cccccc}
\hline Model & & B & $\boldsymbol{\beta}$ & T-value & Sig* \\
\hline \multirow{2}{*}{1} & Constant & 52.178 & & 15.327 & 0.000 \\
\cline { 2 - 6 } & Manager's Age & 0.158 & 0.010 & 0.159 & 0.694 \\
\hline
\end{tabular}

\section{Dependent Variable: Project Success}

Table 7 presents the findings of Simple Linear Regression of the association between manager's age and Project Success. Based on simple linear regression analysis, project managers' age did not significantly predict project success. it can be inferred that at an alpha level of 0.05 as project manager's age was had no relationship with project success.

The research findings revealed that the four types of project manager's skills: technical, political, human and conceptual are significantly associated with project success in the Egyptian construction industry. These findings are compatible with most of the relevant academic literature. To manage a construction project professionally and successfully, the project manager needs knowledge and skills (Hwang and Ng, 2013). For instance, Dainty et al (2005) argued that construction project managers need to possess sufficient technical skills to assure effective coordination and communication of many different stakeholders while Khamaksorn (2016) emphasized the importance of scheduling and planning management skills. Similarly, Hwang and Ng (2013) argued that it is essential for project managers to decide the best possible selection of technologies, systems, and subcontractors required for green projects.

With regard to human skills, Delnavaz (2012) stressed the need for project managers to focus on communication in order to deliver the sustainable practices that are expected from the project team while Schmid and Adams (2008) and Zulch (2014) argued that a project manager need to have effective motivational skills to ensure that the project team achieves the project's goals in time and on budget. (Schmid and Adams, 2008). With regard to political skills, researchers paid attention to those abilities related to understanding others and achieving a win-win situation for both the company and employees and workers (Ferris et al., 2005a; Robichaud and Anantatmula, 2011). These skills involve delegation (Khamaksorn, 
2016), social intelligence, emotional intelligence, trait anxiety, ego-resiliency, social selfefficacy, and general mental ability (Ferris et al., 2005b), conflict management (Giotis, 2010) and coordination between design consultants and the construction team as well as to the technology innovations so that the likelihood of success in green building projects can be enhanced (Li et al., 2013). For conceptual skills, literature emphasized the fundamental skills related to planning, scheduling process and feasibility (Glavinich, 2008; Robichaud and Anantatmula, 2011). In their investigation of project success in Kuwaiti construction industry, Alshammari et al. (2020) stressed the need for managers to have effective planning and training, teamwork, effective communication with staff and contractors, effective resource management, and risk management skills. Patanakul and Milosevic (2009) indicated that project manager must create strong relations with the team members to meet the project objectives along with considering customers' expectations. Fisher (2011) argued that project managers need to possess five skills for in order to achieve project success namely ability to understand various behavioral characteristics of the team members, effective leadership style, ability to influence and motive work team, recognize the conflict sources and solve it and the awareness toward the cultural differences of the work members.

Further, the research findings revealed no relationship between product managers age and project success. Such findings are consistent with the studies conducted by (Hoxha and Mcmahan, 2019; Chipulu et al., 2014; Larsson et al., 2015) who argued that project managers' age did not significantly predict project success. Based on these research findings, construction companies need to focus on developing project manager's skills and not to consider project manager's age as a determinant of project success.

\section{CONCLUSION}

Project manager's skills are essential for ensuring project success in the construction industry. The research findings revealed that project managers maintain a competitive level of technical, conceptual, political and human skills. In addition, project managers pay increasing attention to specific measures of cost, schedule and quality dimensions of project success. The regression analysis revealed that all technical, conceptual, political, and political skills are significantly related to project success, while project manager's age had no association with project success.

The fundamental contribution of this study lies in examining a comprehensive set of project management skills: conceptual, technical, political and human skills in relation to project success in construction industry. Such categorization of project manager's skills involves all skills related to managing time, financial and human resources, control issues, and cover all dimensions and activities pertaining to project success. Further, this study advocates the need to distinguish age and experience of a project managers and not to overemphasize the project manager's age when selecting a manager to handle a specific construction project.

This research has some limitations. First, generalizing research findings might be challenged because the research sample was drawn randomly as the exact number of construction project managers in Egypt is unknown. Further, this research didn't' pay attention the nature of projects as some construction projects might be simple while others might be complex.

Further research may examine the applicability of technical, political, conceptual and human skills in achieving project success in different industries, different contexts and in complex projects. In addition, examining how project managers develop and apply their project management skills presents a promising research avenue. Further research may focus on examining the relationship between project manager's age and project success with emphasis on young managers and distinction between manager's age and work experience. 


\section{REFERENCES}

Adams, H. (2016), A different approach to project management: The use of soft skills, Master Thesis, Harrisburg University. available at: http://digitalcommons.harrisburgu.edu/pmgt_dandt/2 (accessed 10 August 2020).

Ahearn, K.K., Ferris, G.R., Hochwarter, W.A. et al. (2004), "Leader political skill and team performance'", Journal of Management, Vol. 30, No. 3, pp. 309-27. http://dx.doi.org/10.1016/j.jm.2003.01.004.

Ali, M.A. and Chileshe, N. (2009), "The influence of the project manager on the success of the construction projects", in 3rd International Conference on Construction Engineering and Management (ICCEM) 'Global Convergence in Construction', Jeju, Korea.

Al-Shaaby, A.A. and Almessabi, A. (2018), "How do we measure project success? A Survey", Journal of Information Technology \& Software Engineering, Vol. 8, No. 2, pp. 1-5. http://dx.doi.org/10.4172/21757866.1000229.

Alshammari, F., Yahya, K. and Binti Haron, Z. (2020), "Project Manager's Skills for improving the performance of complex projects in Kuwait Construction Industry: A Review", IOP Conference Series. Materials Science and Engineering, Vol. 713, pp. 012041. http://dx.doi.org/10.1088/1757899x/713/1/012041.

Alzahrani, J.I. and Emsley, M.W. (2013), "The Impact of Contractors' Attributes on Construction Project Success: A Post Construction Evaluation", International Journal of Project Management, Vol. 31, No. 2, pp. 313-322. http://dx.doi.org/10.1016/j.ijproman.2012.06.006.

Atkinson, R. (1999), "Project management: cost, time and quality, two best guesses and a phenomenon, it is time to accept other success criteria", International Journal of Project Management, Vol. 17, No. 6, pp. 337-42.

Blaskovics, B. (2016), "The impact of project manager on project success-The case of ICT sector", Society and Economy in Central and Eastern Europe, Vol. 38, pp. 261-81. http://dx.doi.org/10.1556/204.2016.38.2.7.

Bryman, A. (2012), "Social Research Methods", 4th ed., Oxford University Press, Oxford.

Chan, A.P.C. and Chan, A.P.L. (2004), "Key performance indicators for measuring construction success", Benchmarking, Vol. 11, No. 2, pp. 203-21. http://dx.doi.org/10.1108/14635770410532624.

Chen, P., Partington, D. and Wang, J.N. (2008), "'Conceptual determinants of construction project management competence: A Chinese perspective", International Journal of Project Management, Vol. 26, No. 6, pp. 655-64. http://dx.doi.org/10.1016/j.ijproman.2007.09.002.

Chen, P., Partington, D. and Wang, J.N. (2008), "'Conceptual determinants of construction project management competence: A Chinese perspective", International Journal of Project Management, Vol. 26, No. 6, pp. 655-64.

Chipulu, M., Ojiako, U., Gardiner, P. et al. (2014), "Exploring the impact of cultural values on project performance: The effects of cultural values, age and gender on the perceived importance of project success/failure factors", International Journal of Operations \& Production Management, Vol. 34, pp. 36489. http://dx.doi.org/10.1108/ijopm-04-2012-0156.Dainty, A.R.J., Cheng, M.-I. and Moore, D.R. (2005), "'Competency-Based Model for Predicting Construction Project Managers", Performance", Journal of Management Engineering, Vol. 21, No. 1, pp. 2-9. http://dx.doi.org/10.1061/(asce)0742597x(2005)21:1(2).

Dainty, A.R.N., Cheng, M.I. and Moore, D.R. (2003), "Redefining performance measures for construction project managers: an empirical evaluation", Construction Management and Economics, Vol. 21, No. 2, pp. 209-18. http://dx.doi.org/10.1080/0144619032000049737.

Delnavaz, M. (2012), Project Managers' Role in Sustainable Building Process, Master's thesis, Chalmers University of Technology, Goteborg, Sweden.

Doloi, H. (2009), "Analysis of pre-qualification criteria in contractor selection and their impacts on project success", Construction Management and Economics, Vol. 27, pp. 1245-63.

El-Sabaa, S. (2001), "The skills and career path of an effective project manager", International Journal of Project Management, Vol. 19, No. 1, pp. 1-7.

El-sokhn, N.H. and Othman, A.A.E. (2014). "Project failure factors and their impacts on the construction industry: a literature review" in 10th International Conference on Civil and Architecture Engineering, Cairo, Egypt. available at: https://www.researchgate.net/publication/271906893. 
Farooqui, R.U., Saqib, M. and Ahmed, S.M. (2008), "Assessment of critical skills for project managers in Pakistani construction industry" in ICCIDC-I: First International Conference on Construction in Developing Countries, 4-5 August, Karachi, Pakistan.

Farooqui, R.U. (2008). "An exploratory study probing into the factors causing safety non-performance in the Pakistani construction industry" in 45th IEP Convention, pp. 1-12.

Ferris, G.R., Perrewé, P.L., Anthony, W.P. et al. (2005a), "Political Skill at Work: Impact on Work Effectiveness", Davies-Black Publishing, Mountain View, CA.

Ferris, G.R., Treadway, D.C., Kolodinsky, R.W. et al. (2005b), "Development and validation of the political skill inventory", Journal of Management, Vol. 31, No. 1, pp. 126-52.

Fisher, E. (2011), "What practitioners consider to be the skills and behaviours of an effective people project manager", International Journal of Project Management, Vol. 29, pp. 994-1002.

Foley, J. and Macmillan, S. (2005), "Patterns of interaction in construction team meetings", CoDesign, Vol. 1, No. 1, pp. 19-37. http://dx.doi.org/10.1080/15710880412331289926.

Gillard, S. and Price, J. (2005), "The competencies of effective project managers: A conceptual analysis", International Journal of Management, Vol. 22, No. 1, pp. 48-53.

Giotis, T.C. (2010), "Leadership through conflict: grow and advance project teams", Paper presented at PMI ${ }^{\circledR}$ Global Congress 2010_EMEA, Milan, Italy. Newtown Square, PA: Project Management Institute.

Glavinich, T.E. (2008). “Contractor's guide to green building construction”, New Jersey: John Wiley \& Sons

Goodwin, R.S.C. (1993), "'Skills required of effective project managers", Journal of Management Engineering, Vol. 9, No. 3, pp. 217-26.

Gunduz, M. and Yahya, A. (2018), "Analysis of project success factors in construction industry", Technological and Economic Development of Economy, Vol. 24, No. 1, pp. 67-80. http://dx.doi.org/10.3846/20294913.2015.1074129.

Gushgari, S.K., Francis, P.A. and Saklou, J.H. (1997), "Skills critical to long-term profitability of engineering firms", Journal of Management Engineering, Vol. 13, No. 2, pp. 46-56. http://dx.doi.org/10.1061/(ASCE)0742-597X(1997)13:2(46).

Hair, J., Black, W., Babin, B. et al. (2006), Multivariate data analysis, 6th ed., NJ Pearson Prentice Hall, Upper Saddle River.

Hoxha, L. and Mcmahan, C. (2019), "The Influence of Project Manager's Age on Project Success", Journal of Engineering, Project, and Production Management, Vol. 9, No. 1. http://dx.doi.org/10.2478/jeppm2019-0003.

Hughes, S.W., Tippett, D.D. and Thomas, W.K. (2004), "Measuring project success in the construction industry", Engineering Management Journal, Vol. 16, No. 3, pp. 31-7. http://dx.doi.org/10.1080/10429247.2004.11415255.

Hwang, B. and Ng, W. (2013), "Project management knowledge and skills for green construction: Overcoming challenges", International Journal of Project Management, Vol. 31, pp. 272-84.

Jiang, W., Lu, Y. and Le, Y. (2016), "Trust and project success: A twofold perspective between owners and contractors", Journal of Management Engineering, Vol. 32, No. 6. http://dx.doi.org/10.1061/(ASCE)ME.1943-5479.

Katz, R.L. (1974), "Skills of an effective administrator", Harvard Business Review, Vol. 33, pp. 90-102.

Kerzner, H. (2009), "Project Management: A System Approach to Planning, Scheduling, and Controlling", 10th ed., Wiley, Hoboken, NJ.

Khamaksorn, A. (2016), "Project Management Knowledge and Skills for the Construction Industry", in International Conference on Civil, Architecture and Sustainable Development, London, UK. https://doi.org/10.15242/IICBE.DIR1216416.

Khan, K., Turner, J.R. and Maqsood, T. (2013), "Factors that Influence the Success of Public Sector Projects in Pakistan", in Proceedings of IRNOP 2013 Conference, BI Norwegian Business School, Oslo, Norwa. http://dx.doi.org/10.13140/2.1.4832.9605.

Lain, D. and Loretto, W. (2016), "Managing employees beyond age 65: From the margins to the mainstream", Employee Relations, Vol. 38, pp. 646-64. http://dx.doi.org/10.1108/ER-04-2015-0062. 
Larsson, J., Eriksson, P.E., Olofsson, T. et al. (2015), "Leadership in civil engineering: Effects of project managers' leadership styles on project performance", Journal of Management Engineering, Vol. 31, No. 6. http://dx.doi.org/10.1061/(ASCE)ME.1943-5479.0000367.

Lei, W. and Skitmore, M. (2004), "Project management competencies: a survey of perspectives form project managers in South East Queensland", Journal of Building and Construction Management, Vol. 9, No. 1, pp. 1-12.

Lei, W.W.S. and Skitmore, M. (2004), "Project management competencies: A survey of perspectives from project managers in South East Queensland", Journal of Building and Construction Management, Vol. 9, No. 1, pp. 1-12.

Li, Y. Y., Chen, P. H., Chew, D. A. S., Teo, C. C., \& Xu, Y. Q. (2013), “Project management factors affecting green building projects: case study of Singapore", Applied Mechanics and Materials, Vol. 357-360, pp. 2346-52. http://dx.doi.org/10.4028/www.scientific.net/amm.357-360.2346.

Mainiero, L.A. (1994), "'On breaking the glass ceiling: The political seasoning of powerful women executives", Organizational Dynamics, Vol. 22, No. 4, pp. 5-20.

Muhwezi, L., Acai, J. and Otim, G. (2014), "An assessment of the factors causing delays on building construction projects in Uganda", International Journal of Construction Engineering and Management, Vol. 3, No. 1, pp. 13-23. http://dx.doi.org/10.5923/j.ijcem.20140301.02.

Muller, R.A. (2007), "The influence of project managers on project success criteria and project success by type of project", European Management Journal, Vol. 1, pp. 298-309.

Obradović, V., Montenegro, A. and Bjelica, D. (2018), "Digital era and project manager's competencies", European Project Management Journal, Vol. 8, No. 1. http://dx.doi.org/10.18485/epmj.2018.8.1.1.

Ojiako, U., Chipulu, M., Marshall, A. et al. (2015), "Heterogeneity and perception congruence of project outcomes", Production Planning and Control, Vol. 26, pp. 858-73. http://dx.doi.org/10.1080/09537287.2014.994684.

Olanipekun, A.O., Xia, B.P. and Nguyen, H.T. (2017), "Motivation and owner commitment for improving the delivery performance of green building projects: a research framework", Procedia Engineering, Vol. 180, pp. 71-81.

Omidvar, G., Samad, Z. and Alias, A. (2012), "Project management competency elements valued by project managers in construction industry", International Journal of Research in Management and Technology, Vol. 2, No. 6, pp. 593-602.

Oxford Business Group (2020). Construction \& Real Estate: The Report: Egypt 2020. available at: https://oxfordbusinessgroup.com/egypt-2020/construction-real-estate (accessed 10 August 2020).

Patanakul, P. and Milosevic, D. (2009), "The effectiveness in managing a group of multiple projects: Factors of influence and measurement criteria", International Journal of Project Management, Vol. 27, pp. 216-33.

Peterson, T.O. and Peterson, C.M. (2004), "From felt need to actual need: a multi-method multi-sample approach to needs assessment", Performance Improvement Quarterly, Vol. 17, No. 1, pp. 5-21. http://dx.doi.org/10.1111/j.1937-8327.2004.tb00299.x.

Project Management Inistitut - PMI (2013), “A Guide to the Project Management Body of Knowledge”, 5th ed., Project Management Institute, Newton Square, Pennsylvania.

Rea, K. and Lientz, B. (2002), International project management, 1st ed., New York: Routledge. https://doi.org/10.4324/9780080495477.

Refaat, T. (2020), “Fitch: Egypt to Be MENA's Largest Construction Market by 2029”, See News. available at: https://see.news/fitch-egypt-to-be-menas-largest-construction-market (accessed 10 August 2020).

Robichaud, L.B. and Anantatmula, V.S. (2011), "Greening project management practices for sustainable construction", Journal of Management Engineering, Vol. 27, No. 1, pp. 48-57.

Santoso, D.S. and Kulathunga, H.E.R. (2016), "Examining happiness: towards better understanding of performance improvement", Procedia Engineering, Vol. 164, pp. 354-61. http://dx.doi.org/10.1016/j.proeng.2016.11.630.

Schmid, B. and Adams, J. (2008), "Motivation in project management: the project manager's perspective", Project Management Journal, Vol. 39, No. 2, pp. 60-71.

Schreiber, S. (2015), Leadership and Aging Workforces: Effects of Leader's Relative Age on Team's and Leader's Effectiveness. Doctoral Dissertation, Heidelberg University, Heidelberg, Germany. available at: http://www.ub.uni-heidelberg.de/archiv/19867 (accessed 10 August 2020). 
Serhan, N. (2016), “Project manager's communication skills and stakeholder engagement in sustainable construction projects". Master Thesis, Malmo University.

Sigurðarson, S. F. (2009), Critical Success Factors in Project Management: An ethical perspective, Master's Thesis, University of Iceland, Reykjavík, Islândia.

Silva, S., Warnakulasuriya, B. and Arachchige, B. (2019). "A Scale for Measuring Perceived Construction Project Success - Sri Lankan Perspective", Studies in Business and Economics, Vol. 14, No. 1, pp. 245-258.

Spencer, L.M. and Spencer, S. (1993), Competence at Work: Models for Superior Performance, Wiley, New York. https://doi.org/10.1002/hrdq.3920050411.Standish Group (2015), “Standish group 2015 chaos report", available at: https://www.infoq.com/articles/standish-chaos-2015 (accessed 10 August 2020).

Sunindijo, R.Y. (2015), "Project manager skills for improving project performance", International Journal of Business Performance Management, Vol. 16, No. 1. http://dx.doi.org/10.1504/ijbpm.2015.066041.

Sunindijo, R.Y. and Zou, P.X.W. (2012), "Political skill for developing construction safety climate", Journal of Construction Engineering and Management, Vol. 138, No. 5, pp. 605-12.

Wai, S.H., Yusof, A.M., Ismail, S. et al. (2012), "Exploring success factors of social infrastructure projects in Malaysia", International Journal of Engineering Business Management, Vol. 5, pp. 4. http://dx.doi.org/10.5772/55659.

Wateridge, J. (1998), "How can IS/IT projects be measured for success", International Journal of Project Management, Vol. 16, No. 1, pp. 59-63. http://dx.doi.org/10.1016/s0263-7863(97)00022-7.

Zare, M.B., Mirjalili, A. and Mirabi, M. (2016), "Ranking and evaluating the factors affecting the success of management team in construction projects", Journal of Fundamental and Applied Sciences, Vol. 8, pp. 614-30.

Zulkiffli, N.A and Lattifi, A.A. (2019), "Review on Project Manager's Leadership Skills in the Pre-Construction Phase of Sustainable Construction Projects", MATEC Web of Conferences, Vol. 266, No. 1, pp. 1-7. https://doi.org/10.1051/matecconf/2019/2018/2661026601011ConBEE11.

Zulch, B.G. (2014), "Communication skills impact on sustainable and green project management", in Proceedings of the World Sustainable Building (SB14) Conference, Barcelona, Spain, Vol. 5, pp. 676-82.

Author contributions: Authors contributed equally to this paper. 